RESEARCH ARTICLE

Published May 19, 2020

\title{
Antiretroviral Treatment for HIV Elite Controllers?
}

\section{AUTHORS}

Ezequiel Ruiz-Mateos ${ }^{1}$, Eva Poveda ${ }^{2}$, Michael M. Lederman ${ }^{3}$

\section{AFFILIATED INSTITUTIONS}

${ }^{1}$ Clinic Unit of Infectious Diseases; Microbiology and Preventive Medicine; Institute of Biomedicine of Seville; Virgen del Rocío University Hospital/CSIC/University of Seville, Spain

${ }^{2}$ Group of Virology and Pathogenesis; Galicia Sur Health Research Institute (IIS Galicia

Sur)-Complexo Hospitalario Universitario de Vigo; SERGAS-UVigo; Vigo, Spain

${ }^{3}$ Division of Infectious Diseases; Center for AIDS Research; Case Western Reserve University and University Hospitals; Cleveland Medical Center; Cleveland, Ohio

CORRESPONDING AUTHOR

Michael M. Lederman

University Hospitals/Cleveland Medical Center

2061 Cornell Rd.

Cleveland, OH 44118

MXL6@case.edu

\section{SUGGESTED CITATION}

Ruiz-Mateos E, Poveda E, Lederman MM. Antiretroviral Treatment for HIV Elite Controllers? Pathogens and Immunity. 2020;5(1):68-92. PubMed PMID. doi: 10.20411/pai.v5i1.364

\section{ABSTRACT}

In most HIV-infected persons, the natural history of untreated infection is one of sustained viremia, progressive $\mathrm{CD} 4 \mathrm{~T}$ cell depletion with resultant morbidity and mortality. The advent of effective combination antiretroviral therapy (ART) that controls HIV replication has altered this landscape dramatically. Yet a rare population of HIV-infected persons-elite controllers (EC)can control HIV replication such that plasma levels of virus are "undetectable" without ART. The EC phenotype is heterogeneous, with some subjects durably controlling the virus-persistent elite controllers - and some eventually losing viral control - transient elite controllers. Overall, $\mathrm{EC}$ tend to have robust HIV-specific $\mathrm{T}$ cell responses and in some cases, mainly in transient elite controllers, elevated activation and inflammation indices that diminish with ART suggesting that 
endogenous defenses against this persistent pathogen come at the cost of heightened activation/ inflammation. A limited data set suggests that cardiovascular disease risk as well as the occurrence of other morbid events may be greater in the overall EC population than in treated HIV infection. ART in EC decreases activation indices but does not appear to increase circulating CD4 T cell numbers nor do we know if it alters clinical outcomes. Thus, it is difficult to recommend or discourage a decision to start ART in the EC population but the authors lean toward treatment particularly in those EC whose activation indices are high and those who are progressively losing circulating CD4 T cell numbers. Biomarkers that can reliably predict loss of virologic control and immune failure are needed.

Keywords: Elite Control; HIV; Immune Activation; Inflammation; Cardiovascular Disease; Transmission

\section{INTRODUCTION}

\section{Definition of Elite Control}

Elite controllers (EC) represent a rare subset of persons living with HIV infection who somehow manage to control HIV replication in the absence of antiretroviral therapy (ART). Typically comprising between $0.5 \%$ and $1.5 \%$ of populations with HIV infection [1-5], in these persons, plasma levels of HIV are below limits of detection by clinical assays. However, EC represent a heterogeneous population with different definitions based on the length of the follow up, viremia detection limits, presence/absence of blips, and/or CD4+ T cell counts [ㅁ-ㅁ]. Indeed, recent studies were able to identify at least two well-defined phenotypes [9-11]. Overall, persistent EC are those with a length of follow up $>10$ years with plasma levels of HIV under the detection limits in the absence of blips and CD4+ T-cell counts $>500$ cells $/ \mathrm{mm}^{3}$; this contrasts with transient EC who with time, lose virologic control (Table 1). The subset of elite controllers characterized as "exceptional elite controllers," variably described with low levels of HIV antibodies, low HIV reservoir levels including low levels of replication competent virus, low systemic levels of inflammation appear to overlap largely with controllers who durably control HIV replication [ㅁ-며]

In general, EC may represent the far end of a continuum of virologic control as the range of viremia in persons living with HIV infection is broad, yet there are some characteristics of EC that suggest the presence of specific protective mechanisms. Some groups have identified a relatively high prevalence of virologic control among HIV infected persons who began ART relatively early in the course of infection [14]. These "post-treatment controllers" will not be discussed here.

Some instances have been described wherein the viruses of EC have appeared to be defective or less fit $[\underline{15}, \underline{16}]$, however there is increasing evidence that host factors may be particularly important in determining the ability to control HIV replication in EC. Persons with the EC phenotype often carry the HLA-B57 or B27 allele suggesting the importance of adaptive immunity and the role of CD8+ T cells in mediating this protection, however not all EC are HLA-B57+ or B27+ and not all HLA-B57+ or -B27+ persons who are HIV infected are EC. Interestingly, both CD8+ T cell responses tend to be brisk and polyfunctional in persons who control HIV replication [1719]. Resident CD8+ T cells at lymphoid sites of HIV replication are enriched for expression of genes with effector function [20] and mucosal CD8+ T cells reactive with HIV peptides tend to be more potent and polyfunctional [21]. Moreover, HIV-specific CD4+ T cell responses are characteristically preserved in EC [르] and while it is plausible and likely that these immune defense are 
important in virologic control, it is also possible that virologic control and the absence of viremia-mediated immune suppression [르] promote a bidirectional environment that also protects $\mathrm{T}$ cell function that controls HIV replication.

Table 1. Immunologic and virologic characteristics of persistent and transient elite controllers.

\begin{tabular}{lcc}
\hline & Persistent EC & Transient EC \\
\hline Viral Blips $[\underline{8}, \underline{9}, \underline{30}]$ & Absence & Presence \\
\hline $\begin{array}{l}\text { Immune Activation/Inflamma- } \\
\text { tion }[\underline{9}, \underline{10}, \underline{11}, \underline{30}]\end{array}$ & Low & High \\
\hline $\begin{array}{l}\text { HIV-specific T-cell response } \\
\text { levels }[\underline{10}, \underline{12}, \underline{13}]\end{array}$ & High & Low \\
HIV genetic diversity $[\underline{10}, \underline{13}]$ & Low & High \\
\hline $\begin{array}{l}\text { HIV Reservoir Size }[\underline{9}, \underline{10}, \underline{12} \\
\underline{13}]\end{array}$ & Low & Low \\
\hline
\end{tabular}

Intrinsic relative resistance of CD4+ T cells to HIV infection has been found in some [24] studies

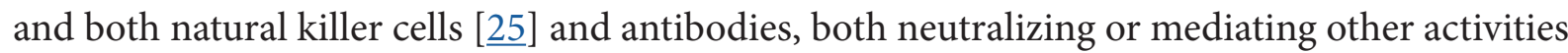
$[\underline{26}, \underline{27}]$ have been implicated in the control of HIV replication in some EC.

Finally, several of these mechanisms have also served to differentiate persistent and transient elite controllers. Persistent controllers have brisk HIV-specific T-cell responses [10], associated with low viral genetic diversity and variability together with lower measures of the HIV reservoir [ $\underline{9}$, 10] compared to these indices in transient controllers. Likewise, persistent controllers show lower levels of systemic inflammation [10]. Additionally, these two phenotypes also differ in a peculiar proteomic profile associated with lower levels of inflammation in persistent controllers than in transient controllers [11]. Also metabolomic and lipidomic profiles are distinguishable between these two groups [28]. Additional studies are needed to validate biomarkers that reliably segregate these two subsets of controllers.

\section{Natural Course of HIV infection in EC}

EC tend to have a relatively stable disease course even in the absence of ART with a much slower progression to AIDS defining events and a less frequent CD4 T cell decline to absolute counts $<$ 350/ $\mu \mathrm{L}$ [29]. CD4 T cell numbers appear to be stable particularly in EC who do not experience viral blips periods [30]. Yet one cohort study demonstrated frequent hospitalizations among EC and an apparent increased risk for cardiovascular complications in EC when compared to the occurrence of these events in HIV infected persons who were receiving ART [31]. However, analyzing a younger, different cohort with lower prevalence of HCV coinfection, these authors did not find differences in the rate of non AIDS events among EC compared to ART treated persons [32]. Likewise, in the Spanish AIDS Research Network HIV Controllers Cohort (ECRIS), lower incidence of non AIDS events were found in EC than in non controllers [33]. 
Also among $204 \mathrm{EC}$ from ECRIS, a loss of virologic control occurred at a rate of $4 \%$ per year and a $25 \%$ or greater decrease in circulating CD4 $\mathrm{T}$ cell counts was observed in $6 \%$ of subjects [34]. These losses were not always concordant and there were 0.4 AIDS or death events per 100 person-years of follow up in EC [34]. The EC phenotype appeared to be common among HCV co-infected persons in some cohorts $[\underline{34}, \underline{35}]$.

In a number of studies performed among HIV infected persons receiving ART, high levels of inflammatory markers are associated with an increased risk of morbid events [36-38]. Plasma levels of inflammatory mediators including some mediators that were linked to these morbid outcomes were higher in EC than among ART treated subjects $[\underline{39}, \underline{40}]$ but none were linked to levels of residual viremia or $\mathrm{CD} 4$ decline [41]. In a small study among $14 \mathrm{EC}$ who lost virologic control (transient controllers) and $18 \mathrm{EC}$ who sustained it (persistent controllers) lower levels of HIV Gag-specific T cell polyfunctionality as well as heightened T cell activation appeared to predict the loss of virologic control [미].

It is not clear whether the heightened inflammation seen in some EC is linked to risk or to protection. In the study by Jacobs et al, a large panel of 87 plasma cytokines were examined by multiplexed assays [42]. Of these, 4 were elevated in EC and not in plasmas of non controllers or ART treated persons. When applied in combination, these cytokines could increase expression of the HIV restriction factors interferon inducible transmembrane proteins (IFITM1/2). Whether this effect is operative in vivo is not clear as a variety of additional effects on cellular activation and coreceptor expression were observed as well. In a small study performed among $10 \mathrm{EC}$ and in which comparisons were made to subjects reported in earlier studies, there appeared to be elevated plasma levels of monocyte activation markers (sCD163 and sCD14) than seen among ART treated patients and an increased prevalence of coronary artery plaque (by angiography) when compared with healthy donors but not with ART treated patients [ $\underline{43}$ ]. In another larger study, EC had greater carotid intima -media thickness (IMT) and higher levels of $C$ reactive protein in plasma than did HIV seronegative controls even when corrected for other risk factors, although there were no differences with ART treated persons [ㄴ4].

\section{Treatment of Elite Controllers}

Hatano et al treated HIV controllers with ART (raltegravir/tenofovir and emtricitibine) for 24 weeks [도] . Using sensitive measurements, they found that ART decreased levels of HIV in plas$\mathrm{ma}$ and in mucosal sites. Indices of $\mathrm{T}$ cell activation fell in peripheral blood and rectal mucosa and there were trends to modest decreases in plasma markers of immune activation (CRP, IL-6, sCD14, and D-dimer) indices that are often linked to morbid outcomes in HIV infection. Circulating CD4+ T cell counts did not increase. It should be noted that only four of these 16 subjects had plasma viral load levels less than 40 copies $/ \mathrm{mL}$ at treatment initiation. In these four subjects authors found the same results regarding sensitive viral load assays, but no differences were found in $T$ cell activation indices. In another study of 35 controllers of whom 11 were EC, administration of ART regimen for up to 48 weeks, decreased indices of CD4+ and CD8+ T cell activation and decreased plasma levels of IP-10 but had no effect on circulating CD4+ T cell counts and actually increased plasma levels of the monocyte activation marker sCD163. The effects of treatment on activation indices was greater in those persons with higher levels of pre-treatment viremia [46]. In another small study, Kim et al treated four EC with a standardized ART regimen (raltegravir/tenofovir/emtricitibine) for 9 months. At baseline, levels of IL-6 and D-dimer were 
higher and CD4/CD8 ratios were lower in these persons than in uninfected controls. Treatment increased CD4/CD8 ratios but did not affect IL6 levels, D-dimer levels or indices of microbial translocation or gut CD4 T cell subsets [47]. In a larger study of EC where virologic control was defined as plasma levels of virus $<400$ copies/mL, EC were treated with ART [48]. In contrast to persons who were not virologic controllers at ART initiation, the treated EC did not experience the typical rapid first phase CD4 T cell increase in blood $[\underline{49,50]}$ that is thought to represent a redistribution of sequestered lymphocytes from lymphoid tissues $[51,52]$, but their second phase slower CD4 T cell increase was similar to that experienced by viremic subjects [48].

In the current treatment era, there is increasing emphasis on the development of strategies to cure HIV infection [ [53] and in this regard, a reservoir of immune cells latently infected with replication competent HIV represents a barrier to HIV eradication [54]. Chun et al demonstrated that the pool of circulating CD4+ T cells that contained replication competent HIV was diminished in EC after ART [55] suggesting that this pool is maintained in EC by ongoing HIV replication and that application of ART in EC can get patients "closer" to cure.

It is important to note these studies did not discriminate between persistent and transient elite controllers and we don't know if ART affects these two subsets of EC differently. The validation of biomarkers distinguishing these two groups of controllers with undetectable viremia would be very useful to gauge the effects of ART in these populations.

\section{SUMMARY}

\section{Rationale for antiretroviral treatment (or not) for elite controllers}

Most EC can maintain control of HIV replication, while some lose control over time; we are not yet able to reliably discriminate between these groups before control is lost. A marker or collection of markers that reliably distinguish between these groups would be helpful in deciding whether antiretroviral treatment is warranted. While confirmatory data from large studies are needed, emerging data provide some distinction between transient and durable controllers. Specifically, the absence of viral blips [9] , lower plasma inflammatory chemokine levels [10, 13], lower cellular proviral DNA levels $[\underline{9}, \underline{10}, \underline{12}]$, lesser viral diversity $[\underline{10}, \underline{13}]$ and brisk HIV-specific T-cell response $[\underline{10}, \underline{12}]$ and absence of replication-competent virus in blood samples [12, 13] may allow distinction of durable controllers from those who are at risk for losing this status. Recent studies identifying proteomic and metabolomics signatures also may prove useful in distinguishing these groups $[\underline{11}, \underline{28}]$. Most EC remain well clinically but there is some evidence that EC are at risk for cardiovascular disease and may experience more frequent hospitalization events, although this finding has not been reproduced. Immune activation is increased in some EC and some of these activation indices are linked to risk for morbid events (including cardiovascular events). Emerging evidence suggests that ART can decrease the magnitude of residual HIV replication and decrease some elevated activation indices. It is likely that some component of this activation is a consequence of the sustained activation of immune defenses against HIV that are protective as HIV-specific immune responses diminish when virus replication is attenuated pharmacologically rather than immunologically. Thus it is reasonable to propose that endogenous immune control of HIV may come at a cost, at least in a subset of EC. So should EC be treated with ART? We still don't know whether ART-induced control of HIV replication is associated with demonstrable clinical benefit in this setting and it isn't likely that a clinical trial will be powered 
to test this question, and although modern ART regimens are relatively well-tolerated, different regimens have recognized toxicities such as weight gain [ $[\underline{6}, \underline{57}]$, lipid and other metabolic per-

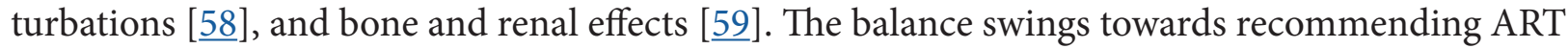
to EC who lose virologic control or are at greater risk for loss of virologic control and to viremic controllers in whom activation indices fall more dramatically with treatment. It is less clear that ART confers clinical benefit to EC with high CD4+ T-cell counts and low levels of inflammation. Some EC may be comforted with ART initiation hoping that this might provide additional protection against transmission to their sexual partners. Nonetheless to our knowledge there are no documented instances of sexual HIV transmission from an EC and a very small study has failed to detect HIV sequences in the semen of four EC but did detect sequences in persons with measurable virus in plasma [60]. Too, an argument can be made to initiate ART in EC before CD4 T cell numbers fall as these numbers do not appear to recover with ART. In this sense, for those EC with decreased CD4 T cell counts, trials of immunomodulators together with ART should be considered. In summary, we would lean more towards recommending a well-tolerated treatment regimen for EC, particularly those whose activation indices are high and those who progressively lose circulating CD4 T cell numbers but there are insufficient data to support such a recommendation definitively. There is a need to find the most predictive biomarkers that can reliably identify those EC who will lose virologic control and those who will experience immunologic failure. This information could help define a population of EC more likely to benefit from intervention as we learn more about the determinants of virologic control, immune defense, and the characteristics of functional cure or possibly even HIV eradication.

\section{POTENTIAL CONFLICTS OF INTEREST}

Co-author Michael M. Lederman is the Editor-in-Chief of Pathogens and Immunity.

\section{ACKNOWLEDGMENTS}

This work was supported by the Case Western Reserve University Center for AIDS Research (CFAR) NIH AI -036219. E. R-M was supported by Consejería de Salud y Bienestar Social of Junta de Andalucía through the Nicolás Monardes Program (C-0032/17) and Fondo de Investigación Sanitaria, Instituto de Salud Carlos III, Fondos Europeos para el Desarrollo Regional, FEDER, grants PI16/00684, PI19/01127, RETICS, Red de Investigación en SIDA (RD16/0025/0020). E.P. was supported by Plan Estatal de I+D+I 2013-2016 and 2017-2020 and co-financed by Instituto de Salud Carlos III (ISCIII)-Subdirección General de Evaluación y Fomento de la investigación del Fondo Europeo de Desarrollo Regional (FEDER) PI16/02159, BA18/00034, PI19/00747, RETICS, Red de Investigación en SIDA (RD16/0025/0026). Thanks to Jonathan Li, Steven Deeks, and Peter Hunt for advice.

\section{REFERENCES}

1. Blankson JN. Effector mechanisms in HIV-1 infected elite controllers: highly active immune responses? Antiviral research. 2010;85(1):295-302. PubMed PMID: PMC2814919. doi: 10.1016/j.antiviral.2009.08.007

2. Deeks SG, Walker BD. Human immunodeficiency virus controllers: mechanisms of durable virus control in the absence of antiretroviral therapy. Immunity. 2007;27(3):406-16. doi: 10.1016/j.immuni.2007.08.010 
3. Gonzalo-Gil E, Ikediobi U, Sutton RE. Mechanisms of Virologic Control and Clinical Characteristics of HIV+ Elite/Viremic Controllers. The Yale journal of biology and medicine. 2017;90(2):245-59. PubMed PMID: PMC5482301.

4. Lambotte O, Boufassa F, Madec Y, Nguyen A, Goujard C, Meyer L, Rouzioux C, Venet A, Delfraissy JF. HIV controllers: a homogeneous group of HIV-1-infected patients with spontaneous control of viral replication. Clinical infectious diseases : an official publication of the Infectious Diseases Society of America. 2005;41(7):1053-6. doi: $10.1086 / 433188$

5. Okulicz JF, Lambotte O. Epidemiology and clinical characteristics of elite controllers. Current opinion in HIV and AIDS. 2011;6(3):163-8. doi: 10.1097/COH.0b013e$328344 \mathrm{f} 35 \mathrm{e}$

6. Olson Ashley D. Olson, Laurence Meyer, Maria Prins, Rodolphe Thiebaut, Deepti Gurdasani, Marguerite Guiguet, Marie-Laure Chaix, Pauli Amornkul, Abdel Babiker, Manjinder S. Sandhu, Kholoud Porter, for C. A. S. C. A. D. E. Collaboration in EuroCoord. An evaluation of HIV elite controller definitions within a large seroconverter cohort collaboration. Plos One. 2014;9(1):e86719.

7. Gurdasani D(1), Iles L, Dillon DG, Young EH, Olson AD, Naranbhai V, Fidler S, Gkrania-Klotsas E, Post FA, Kellam P, Porter K, Sandhu MS. A systematic review of definitions of extreme phenotypes of HIV control andprogression. AIDS. 2014 Jan $14 ; 28(2): 149-62$.

8. Chereau F, Madec Y, Sabin C, Obel N, Ruiz-Mateos E, Chrysos G, Fidler S, Lehmann C, Zangerle R, Wittkop L, Reiss P, Hamouda O, Estrada Perez V, Leal M, Mocroft A, Garcia De Olalla P, Ammassari A, D’Arminio Monforte A, Mussini C, Segura F, Castagna A, Cavassini M, Grabar S, Morlat P, De Wit S, Lambotte O, Meyer L; HIV Controllers Project Working Group for the Collaboration of Observational HIV Epidemiological Research Europe (COHERE) in EuroCOORD. Impact of CD4 and CD8 dynamics and viral rebounds on loss of virological control in HIV controllers. PLoS One. 2017;12(4):e0173893.

9. Canoui E, Lecuroux C, Avettand-Fenoel V, Gousset M, Rouzioux C, Saez-Cirion A, Meyer L, Boufassa F, Lambotte O, Noel N. A Subset of Extreme Human Immunodeficiency Virus (HIV) Controllers Is Characterized by a Small HIV Blood Reservoir and a Weak T-Cell Activation Level. Open forum infectious diseases. 2017;4(2):ofx064. PubMed PMID: PMC5450900. doi: 10.1093/ofid/ofx064

10. Pernas M, Tarancon-Diez L, Rodriguez-Gallego E, Gomez J, Prado JG, Casado C, Dominguez-Molina B, Olivares I, Coiras M, Leon A, Rodriguez C, Benito JM, Rallon N, Plana M, Martinez-Madrid O, Dapena M, Iribarren JA, Del Romero J, Garcia F, Alcami J, Munoz-Fernandez MA, Vidal F, Leal M, Lopez-Galindez C, Ruiz-Mateos E. Factors Leading to the Loss of Natural Elite Control of HIV-1 Infection. Journal of virology. 2017. PubMed PMID: PMC5809746. doi: 10.1128/jvi.01805-17

11. Rodriguez-Gallego E, Tarancon-Diez L, Garcia F, Del Romero J, Benito JM, Alba V, Herrero P, Rull A, Dominguez-Molina B, Martinez-Madrid O, Martin-Pena L, Pulido F, Leon A, Rodriguez C, Rallon N, Peraire J, Vilades C, Leal M, Vidal F, Ruiz-Mateos 
E. Proteomic Profile Associated With Loss of Spontaneous Human Immunodeficiency Virus Type 1 Elite Control. The Journal of infectious diseases. 2019;219(6):867-76. doi: 10.1093/infdis/jiy599

12. Mendoza D, Johnson SA, Peterson BA, Natarajan V, Salgado M, Dewar RL, Burbelo PD, Doria-Rose NA, Graf EH, Greenwald JH, Hodge JN, Thompson WL, Cogliano NA, Chairez CL, Rehm CA, Jones S, Hallahan CW, Kovacs JA, Sereti I, Sued O, Peel SA, O'Connell RJ, O’Doherty U, Chun TW, Connors M, Migueles SA. Comprehensive analysis of unique cases with extraordinary control over HIV replication. Blood. 2012;119(20):4645-55. PubMed PMID: PMC3367872. doi: 10.1182/ blood-2011-10-381996

13. Casado C, Galvez C, Pernas M, Tarancon-Diez L, Rodriguez C, Sanchez-Merino V, Vera M, Olivares I, De Pablo-Bernal R, Merino-Mansilla A, Del Romero J, Lorenzo-Redondo R, Ruiz-Mateos E, Salgado M, Martinez-Picado J, Lopez-Galindez C. Permanent control of HIV-1 pathogenesis in exceptional elite controllers: a model of spontaneous cure. Sci Rep. 2020;10(1):1902. PubMed PMID: PMC7002478. doi: 10.1038/s41598-020-58696-y

14. Saez-Cirion A, Bacchus C, Hocqueloux L, Avettand-Fenoel V, Girault I, Lecuroux C, Potard V, Versmisse P, Melard A, Prazuck T, Descours B, Guergnon J, Viard JP, Boufassa F, Lambotte O, Goujard C, Meyer L, Costagliola D, Venet A, Pancino G, Autran B, Rouzioux C. Post-treatment HIV-1 controllers with a long-term virological remission after the interruption of early initiated antiretroviral therapy ANRS VISCONTI Study. PLoS pathogens. 2013;9(3):e1003211. PubMed PMID: PMC3597518. doi: 10.1371/ journal.ppat.1003211

15. Deacon NJ, Tsykin A, Solomon A, Smith K, Ludford-Menting M, Hooker DJ, McPhee DA, Greenway AL, Ellett A, Chatfield C, Lawson VA, Crowe S, Maerz A, Sonza S, Learmont J, Sullivan JS, Cunningham A, Dwyer D, Dowton D, Mills J. Genomic structure of an attenuated quasi species of HIV-1 from a blood transfusion donor and recipients. Science (New York, NY). 1995;270(5238):988-91. PubMed PMID. doi:

16. Lobritz MA, Lassen KG, Arts EJ. HIV-1 replicative fitness in elite controllers. Current opinion in HIV and AIDS. 2011;6(3):214-20. PubMed PMID: PMC5730053. doi: 10.1097/COH.0b013e3283454cf5

17. Almeida JR, Price DA, Papagno L, Arkoub ZA, Sauce D, Bornstein E, Asher TE, Samri A, Schnuriger A, Theodorou I, Costagliola D, Rouzioux C, Agut H, Marcelin AG, Douek D, Autran B, Appay V. Superior control of HIV-1 replication by CD8+ T cells is reflected by their avidity, polyfunctionality, and clonal turnover. The Journal of experimental medicine. 2007;204(10):2473-85. PubMed PMID: PMC2118466. doi: 10.1084/ jem.20070784

18. Migueles SA, Laborico AC, Shupert WL, Sabbaghian MS, Rabin R, Hallahan CW, Van Baarle D, Kostense S, Miedema F, McLaughlin M, Ehler L, Metcalf J, Liu S, Connors M. HIV-specific CD8+ T cell proliferation is coupled to perforin expression and is maintained in nonprogressors. Nature immunology. 2002;3(11):1061-8. PubMed PMID. doi: 10.1038/ni845 
19. Betts MR, Nason MC, West SM, De Rosa SC, Migueles SA, Abraham J, Lederman MM, Benito JM, Goepfert PA, Connors M, Roederer M, Koup RA. HIV nonprogressors preferentially maintain highly functional HIV-specific CD8+ T cells. Blood. 2006;107(12):4781-9. PubMed PMID: PMC1895811. doi: 10.1182/ blood-2005-12-4818

20. Buggert M, Nguyen S, Salgado-Montes de Oca G, Bengsch B, Darko S, Ransier A, Roberts ER, Del Alcazar D, Brody IB, Vella LA, Beura L, Wijeyesinghe S, Herati RS, Del Rio Estrada PM, Ablanedo-Terrazas Y, Kuri-Cervantes L, Sada Japp A, Manne S, Vartanian S, Huffman A, Sandberg JK, Gostick E, Nadolski G, Silvestri G, Canaday DH, Price DA, Petrovas C, Su LF, Vahedi G, Dori Y, Frank I, Itkin MG, Wherry EJ, Deeks SG, Naji A, Reyes-Teran G, Masopust D, Douek DC, Betts MR. Identification and characterization of HIV-specific resident memory CD8(+) T cells in human lymphoid tissue. Science immunology. 2018;3(24). doi: 10.1126/sciimmunol.aar4526

21. Ferre AL, Hunt PW, Critchfield JW, Young DH, Morris MM, Garcia JC, Pollard RB, Yee HF, Jr., Martin JN, Deeks SG, Shacklett BL. Mucosal immune responses to HIV-1 in elite controllers: a potential correlate of immune control. Blood. 2009;113(17):397889. PubMed PMID: PMC2673124. doi: 10.1182/blood-2008-10-182709

22. Porichis F, Kaufmann DE. HIV-specific CD4 T cells and immune control of viral replication. Current opinion in HIV and AIDS. 2011;6(3):174-80. PubMed PMID: PMC3265969. doi: 10.1097/COH.0b013e3283454058

23. Valdez H, Smith KY, Landay A, Connick E, Kuritzkes DR, Kessler H, Fox L, Spritzler J, Roe J, Lederman MB, Lederman HM, Evans TG, Heath-Chiozzi M, Lederman MM. Response to immunization with recall and neoantigens after prolonged administration of an HIV-1 protease inhibitor-containing regimen. ACTG 375 team. AIDS Clinical Trials Group. AIDS (London, England). 2000;14(1):11-21.

24. Saez-Cirion A, Hamimi C, Bergamaschi A, David A, Versmisse P, Melard A, Boufassa F, Barre-Sinoussi F, Lambotte O, Rouzioux C, Pancino G. Restriction of HIV-1 replication in macrophages and CD4+ T cells from HIV controllers. Blood. 2011;118(4):95564. PubMed PMID: PMC3148172. doi: 10.1182/blood-2010-12-327106

25. O’Connell KA, Han Y, Williams TM, Siliciano RF, Blankson JN. Role of natural killer cells in a cohort of elite suppressors: low frequency of the protective KIR3DS1 allele and limited inhibition of human immunodeficiency virus type 1 replication in vitro. Journal of virology. 2009;83(10):5028-34. PubMed PMID: PMC2682110. doi: 10.1128/ jvi.02551-08

26. Ackerman ME, Mikhailova A, Brown EP, Dowell KG, Walker BD, Bailey-Kellogg C, Suscovich TJ, Alter G. Polyfunctional HIV-Specific Antibody Responses Are Associated with Spontaneous HIV Control. PLoS pathogens. 2016;12(1):e1005315. PubMed PMID: PMC4706315. doi: 10.1371/journal.ppat.1005315

27. Gonzalez N, McKee K, Lynch RM, Georgiev IS, Jimenez L, Grau E, Yuste E, Kwong PD, Mascola JR, Alcami J. Characterization of broadly neutralizing antibody responses to HIV-1 in a cohort of long term non-progressors. PloS one. 2018;13(3):e0193773. PubMed PMID: PMC5860703. doi: 10.1371/journal.pone.0193773 
28. Tarancon-Diez L, Rodriguez-Gallego E, Rull A, Peraire J, Vilades C, Portilla I, Jimenez-Leon MR, Alba V, Herrero P, Leal M, Ruiz-Mateos E, Vidal F. Immunometabolism is a key factor for the persistent spontaneous elite control of HIV-1 infection. EBioMedicine. 2019;42:86-96. PubMed PMID: PMC6491381. doi: 10.1016/j.ebiom.2019.03.004

29. Okulicz JF, Marconi VC, Landrum ML, Wegner S, Weintrob A, Ganesan A, Hale B, Crum-Cianflone N, Delmar J, Barthel V, Quinnan G, Agan BK, Dolan MJ. Clinical outcomes of elite controllers, viremic controllers, and long-term nonprogressors in the US Department of Defense HIV natural history study. The Journal of infectious diseases. 2009;200(11):1714-23. doi: 10.1086/646609

30. Cortes FH, de Paula HHS, Bello G, Ribeiro-Alves M, de Azevedo SSD, Caetano DG, Teixeira SLM, Hoagland B, Grinsztejn B, Veloso VG, Guimaraes ML, Morgado MG. Plasmatic Levels of IL-18, IP-10, and Activated CD8(+) T Cells Are Potential Biomarkers to Identify HIV-1 Elite Controllers With a True Functional Cure Profile. Frontiers in immunology. 2018;9:1576. PubMed PMID: PMC6050358. doi: 10.3389/ fimmu.2018.01576

31. Crowell TA, Gebo KA, Blankson JN, Korthuis PT, Yehia BR, Rutstein RM, Moore RD, Sharp V, Nijhawan AE, Mathews WC, Hanau LH, Corales RB, Beil R, Somboonwit C, Edelstein H, Allen SL, Berry SA. Hospitalization Rates and Reasons Among HIV Elite Controllers and Persons With Medically Controlled HIV Infection. The Journal of infectious diseases. 2015;211(11):1692-702. PubMed PMID: PMC4447832. doi: 10.1093/ infdis/jiu809

32. Crowell TA, Ganesan A, Berry SA, Deiss RG, Agan BK, Okulicz JF; Infectious Disease Clinical Research Program (IDCRP) HIV Working Group. Hospitalizations among HIV controllers and persons with medically controlled HIV in the U.S. Military HIV Natural History Study. J Int AIDS Soc. 2016;19(1):20524.

33. Dominguez-Molina B, Leon A, Rodriguez C, Benito JM, Lopez-Galindez C, Garcia F, Del Romero J, Gutierrez F, Viciana P, Alcami J, Leal M, Ruiz-Mateos E. Analysis of Non-AIDS-Defining Events in HIV Controllers. Clin Infect Dis. 2016;62(10):13041309.

34. Leon A, Perez I, Ruiz-Mateos E, Benito JM, Leal M, Lopez-Galindez C, Rallon N, Alcami J, Lopez-Aldeguer J, Viciana P, Rodriguez C, Grau E, Iribarren J, Gatell JM, Garcia F. Rate and predictors of progression in elite and viremic HIV-1 controllers. AIDS (London, England). 2016;30(8):1209-20. doi: 10.1097/qad.0000000000001050

35. Sajadi MM, Pulijala R, Redfield RR, Talwani R. Chronic immune activation and decreased CD4 cell counts associated with hepatitis C infection in HIV-1 natural viral suppressors. AIDS (London, England). 2012;26(15):1879-84. PubMed PMID: PMC3772623. doi: 10.1097/QAD.0b013e328357f5d1

36. Hunt PW, Sinclair E, Rodriguez B, Shive C, Clagett B, Funderburg N, Robinson J, Huang Y, Epling L, Martin JN, Deeks SG, Meinert CL, Van Natta M, Jabs DA, Lederman MM. Gut Epithelial Barrier Dysfunction and Innate Immune Activation Predict Mortality in Treated HIV Infection. J Infect Dis. 2014. doi: 10.1093/infdis/jiu238 
37. Kuller LH, Tracy R, Belloso W, De Wit S, Drummond F, Lane HC, Ledergerber B, Lundgren J, Neuhaus J, Nixon D, Paton NI, Neaton JD. Inflammatory and coagulation biomarkers and mortality in patients with HIV infection. PLoS Med. 2008;5(10):e203. PubMed PMID: PMC2570418. doi: 10.1371/journal.pmed.0050203

38. Tenorio AR, Zheng Y, Bosch RJ, Krishnan S, Rodriguez B, Hunt PW, Plants J, Seth A, Wilson CC, Deeks SG, Lederman MM, Landay AL. Soluble markers of inflammation and coagulation, but not T-cell activation, are predictors of non-AIDS-defining morbid events during suppressive antiretroviral treatment. J Infect Dis. 2014. PubMed PMID. doi: 10.1093/infdis/jiu254

39. Hunt PW, Brenchley J, Sinclair E, McCune JM, Roland M, Page-Shafer K, Hsue P, Emu B, Krone M, Lampiris H, Douek D, Martin JN, Deeks SG. Relationship between T cell activation and CD4+ T cell count in HIV-seropositive individuals with undetectable plasma HIV RNA levels in the absence of therapy. The Journal of infectious diseases. 2008;197(1):126-33. PubMed PMID: PMC3466592. doi: 10.1086/524143

40. Krishnan S, Wilson EM, Sheikh V, Rupert A, Mendoza D, Yang J, Lempicki R, Migueles SA, Sereti I. Evidence for innate immune system activation in HIV type 1-infected elite controllers. The Journal of infectious diseases. 2014;209(6):931-9. PubMed PMID: PMC3935475. doi: 10.1093/infdis/jit581

41. Li JZ, Arnold KB, Lo J, Dugast AS, Plants J, Ribaudo HJ, Cesa K, Heisey A, Kuritzkes DR, Lauffenburger DA, Alter G, Landay A, Grinspoon S, Pereyra F. Differential levels of soluble inflammatory markers by human immunodeficiency virus controller status and demographics. Open forum infectious diseases. 2015;2(1):ofu117. PubMed PMID: PMC4396431. doi: 10.1093/ofid/ofu117

42. Jacobs ES, Keating SM, Abdel-Mohsen M, Gibb SL, Heitman JW, Inglis HC, Martin JN, Zhang J, Kaidarova Z, Deng X, Wu S, Anastos K, Crystal H, Villacres MC, Young M, Greenblatt RM, Landay AL, Gange SJ, Deeks SG, Golub ET, Pillai SK, Norris PJ. Cytokines Elevated in HIV Elite Controllers Reduce HIV Replication In Vitro and Modulate HIV Restriction Factor Expression. Journal of virology. 2017;91(6). PubMed PMID: PMC5331794. doi: 10.1128/jvi.02051-16

43. Pereyra F, Lo J, Triant VA, Wei J, Buzon MJ, Fitch KV, Hwang J, Campbell JH, Burdo TH, Williams KC, Abbara S, Grinspoon SK. Increased coronary atherosclerosis and immune activation in HIV-1 elite controllers. AIDS (London, England). 2012;26(18):2409-12. PubMed PMID: PMC3660105. doi: 10.1097/ QAD.0b013e32835a9950

44. Hsue PY, Hunt PW, Schnell A, Kalapus SC, Hoh R, Ganz P, Martin JN, Deeks SG. Role of viral replication, antiretroviral therapy, and immunodeficiency in HIV-associated atherosclerosis. AIDS. 2009;23(9):1059-67. PubMed PMID: PMC2691772. doi: 10.1097/QAD.0b013e32832b514b

45. Hatano H, Yukl SA, Ferre AL, Graf EH, Somsouk M, Sinclair E, Abdel-Mohsen M, Liegler T, Harvill K, Hoh R, Palmer S, Bacchetti P, Hunt PW, Martin JN, McCune JM, Tracy RP, Busch MP, O’Doherty U, Shacklett BL, Wong JK, Deeks SG. Prospective antiretroviral treatment of asymptomatic, HIV-1 infected controllers. PLoS patho- 
gens. 2013;9(10):e1003691. PubMed PMID: PMC3795031. doi: 10.1371/journal. ppat. 1003691

46. Li JZ, Segal FP, Bosch RJ, Lalama CM, Roberts-Toler C, Delagreverie H, Getz R, Garcia-Broncano P, Kinslow J, Tressler R, Van Dam CN, Keefer M, Carrington M, Lichterfeld M, Kuritzkes D, Yu XG, Landay A, Sax PE; AIDS Clinical Trials Group Study A5308 Team. ART reduces T cell activation and immune exhaustion markers in HIV controllers. Clin Infect Dis. 2020; 70: 1636-1642

47. Kim CJ, Kovacs C, Chun TW, Kandel G, Osborne BJ, Huibner S, Shahabi K, Yue FY, Benko E, Ostowski M, Kaul R. Antiretroviral therapy in HIV-infected elite controllers: impact on gut immunology, microbial translocation, and biomarkers of serious non-AIDS conditions. Journal of acquired immune deficiency syndromes (1999). 2014;67(5):514-8. PubMed PMID: PMC4231825. doi: 10.1097/qai.0000000000000359

48. Boufassa F, Lechenadec J, Meyer L, Costagliola D, Hunt PW, Pereyra F, Deeks S, Pancino G, Taulera O, Lichterfeld M, Delobel P, Saez-Cirion A, Lambotte O. Blunted response to combination antiretroviral therapy in HIV elite controllers: an international HIV controller collaboration. PloS one. 2014;9(1):e85516. PubMed PMID: PMC3894966. doi: 10.1371/journal.pone.0085516

49. Autran B, Carcelain G, Li TS, Blanc C, Mathez D, Tubiana R, Katlama C, Debre P, Leibowitch J. Positive effects of combined antiretroviral therapy on CD4+ T cell homeostasis and function in advanced HIV disease [see comments]. Science. 1997;277(5322):112-6.

50. Lederman MM, Connick E, Landay A, Kuritzkes DR, Spritzler J, St Clair M, Kotzin BL, Fox L, Chiozzi MH, Leonard JM, Rousseau F, Wade M, Roe JD, Martinez A, Kessler H. Immunologic responses associated with 12 weeks of combination antiretroviral therapy consisting of zidovudine, lamivudine, and ritonavir: results of AIDS Clinical Trials Group Protocol 315. J Infect Dis. 1998;178(1):70-9.

51. Bucy RP, Hockett RD, Derdeyn CA, Saag MS, Squires K, Sillers M, Mitsuyasu RT, Kilby JM. Initial increase in blood CD4(+) lymphocytes after HIV antiretroviral therapy reflects redistribution from lymphoid tissues. J Clin Invest. 1999;103(10):1391-8.

52. Mudd JC, Murphy P, Manion M, Debernardo R, Hardacre J, Ammori J, Hardy GA, Harding CV, Mahabaleshwar GH, Jain MK, Jacobson JM, Brooks AD, Lewis S, Schacker TW, Anderson J, Haddad EK, Cubas RA, Rodriguez B, Sieg SF, Lederman MM. Impaired T cell responses to sphingosine-1-phosphate in HIV-1 infected lymph nodes. Blood. 2013. doi: 10.1182/blood-2012-07-445783

53. Lederman MM, Cannon PM, Currier JS, June CH, Kiem HP, Kuritzkes DR, Lewin SR, Margolis DM, McCune JM, Mellors JW, Schacker TW, Sekaly RP, Tebas P, Walker BD, Douek DC. A Cure for HIV Infection: "Not in My Lifetime" or "Just Around the Corner”? Pathogens \& immunity. 2016;1(1):154-64. PubMed PMID: PMC5033048. doi: $10.20411 /$ pai.v1i1.133

54. Finzi D, Hermankova M, Pierson T, Carruth LM, Buck C, Chaisson RE, Quinn TC, Chadwick K, Margolick J, Brookmeyer R, Gallant J, Markowitz M, Ho DD, Richman 
DD, Siliciano RF. Identification of a reservoir for HIV-1 in patients on highly active antiretroviral therapy. Science. 1997;278(5341):1295-300.

55. Chun TW, Shawn Justement J, Murray D, Kim CJ, Blazkova J, Hallahan CW, Benko E, Costiniuk CT, Kandel G, Ostrowski M, Kaul R, Moir S, Casazza JP, Koup RA, Kovacs C, Fauci AS. Effect of antiretroviral therapy on HIV reservoirs in elite controllers. The Journal of infectious diseases. 2013;208(9):1443-7. PMC3789563. doi: 10.1093/infdis/ jit306

56. Venter WDF, Moorhouse M, Sokhela S, Fairlie L, Mashabane N, Masenya M, Serenata C, Akpomiemie G, Qavi A, Chandiwana N, Norris S, Chersich M, Clayden P, Abrams E, Arulappan N, Vos A, McCann K, Simmons B, Hill A. Dolutegravir plus Two Different Prodrugs of Tenofovir to Treat HIV. N Engl J Med. 2019;381(9):803-15. PubMed PMID. doi: 10.1056/NEJMoa1902824

57. Sax PE, Erlandson KM, Lake JE, McComsey GA, Orkin C, Esser S, Brown TT, Rockstroh JK, Wei X, Carter CC, Zhong L, Brainard DM, Melbourne K, Das M, Stellbrink HJ, Post FA, Waters L, Koethe JR. Weight Gain Following Initiation of Antiretroviral Therapy: Risk Factors in Randomized Comparative Clinical Trials. Clinical infectious diseases : an official publication of the Infectious Diseases Society of America. 2019. PubMed PMID. doi: 10.1093/cid/ciz999

58. Lake JE, Currier JS. Metabolic disease in HIV infection. Lancet Infect Dis. 2013;13(11):964-75. PubMed PMID. doi: 10.1016/s1473-3099(13)70271-8

59. Mouton JP, Cohen K, Maartens G. Key toxicity issues with the WHO-recommended first-line antiretroviral therapy regimen. Expert Rev Clin Pharmacol. 2016;9(11):1493503. PubMed PMID. doi: 10.1080/17512433.2016.1221760

60. Chaix ML, Boufassa F, Meyzer C, Leruez-Ville M, Mahjoub N, Nere ML, Genet P, Duvivier C, Lascoux-Combes C, Lambotte O, Ghosn J. Detectable HIV-RNA in semen of HIV controllers. PloS one. 2017;12(8):e0183376. PubMed PMID: PMC5558985. doi: 10.1371/journal.pone.0183376

\section{FOOTNOTES}

Submitted March 9, 2020 | Accepted April 20, 2020 | Published May 19, 2020

\section{COPYRIGHT}

Copyright $\odot 2020$ Pathogens and Immunity

This is an open-access article distributed under the terms of the Creative Commons Attribution 4.0 International License. 